КАРАСЬОВ О. Г., кандидат технічних наук, доцент, доцент кафедри безпеки життєдіяльності (Придніпровська державна академія будівництва та архітектури)

КОЛОМОєЦЬ Ю. О., кандидат юридичних наук, доцент кафедри менеджменту і права (Дніпропетровський державний агроекономічний університет)

ВИПРИЦЬКИЙ А. О., кандидат юридичних наук

DOI https://doi.org/10.32842/2078-3736-2019-6-1-26

\title{
ВІДШКОДУВАННЯ РОБОТОДАВЦЕМ МОРАЛЬНОЇ ШКОДИ: ТРУДОВИЙ ЧИ ЦИВІЛЬНО-ПРАВОВИЙ АСПЕКТ
}

У статті проведено аналіз нормативних актів українського законодавства 3 питань регулювання порядку та розміру відшкодування моральної шкоди у трудових правовідносинах. Визначено основні особливості відшкодування моральної шкоди у трудовому законодавстві.

Необхідно звернути увагу на те, що встановлене Конституцією та законами України право на відшкодування моральної (немайнової) шкоди є важливою гарантією захисту прав і свобод громадян. Тому суди повинні забезпечити своєчасне, у повній відповідності із законом, вирішення справ, пов'язаних з відшкодуванням такої шкоди.

Правовідносини, які виникають при відшкодуванні заподіяної фізичній чи юридичній особі моральної (немайнової) шкоди, регулюються такими нормативно-правовими актами:

- у випадках, передбачених ст. 27 Цивільного кодексу Української та іншим законодавством, яке встановлює відповідальність за заподіяння моральної шкоди (наприклад, ст. 49 Закону «Про інформацію», ст. 44 Закону «Про авторське право і суміжні права»);

- при порушенні зобов'язань, які підпадають під дію Закону «Про захист прав споживачів»;

- у сфері трудових правовідносин (незаконного звільнення або переведення, невиплати належних йому грошових сум, виконання робіт у небезпечних для життя і здоров'я умовах тощо), яке призвело до його моральних страждань, втрати нормальних життєвих зв'язків чи вимагає від нього додаткових зусиль для організації свого життя, обов'язок по відшкодуванню моральної (немайнової) шкоди покладається на власника або уповноважений ним орган незалежно від форми власності, виду діяльності чи галузевої належності підпадають під дію ст. 237-1 Кодекс законів про працю України.

Оскільки питання відшкодування моральної шкоди регулюються законодавчими актами, введеними у дію в різні строки, роботодавцю та працівнику необхідно в кожній випадку з'ясовувати характер правовідносин.

Ключові слова: необхідні умови відповідальності, моральна шкода, розмір відикодування моральної шкоди, порядок відшкодування шкоди.

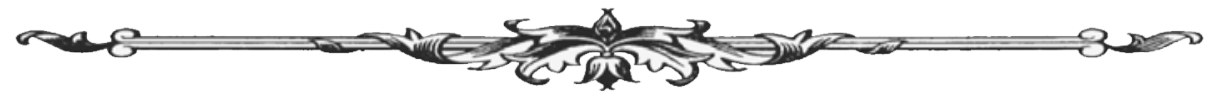


The article analyzes the normative acts of the Ukrainian legislation on the regulation of the order and the amount of compensation for moral harm in labor relations. The main features of compensation for non-pecuniary damage in labor law are identified.

It is necessary to pay attention to the fact that the right established by the Constitution and laws of Ukraine for the compensation of moral (non-pecuniary) damage is an important guarantee for the protection of the rights and freedoms of citizens. Courts should therefore ensure that cases related to compensation for such damage are timely, in full compliance with the law.

Legal relations arising from the compensation of the moral (non-pecuniary) damage caused to an individual or legal entity by the following legal acts:

- in the cases provided for in Article 27 of the Civil Code of Ukraine and other legislation establishing liability for non-pecuniary damage (eg, Article 49 of the Information Law, Article 44 of the Law on Copyright and Related Rights);

- in breach of obligations that fall under the Law on Consumer Protection;

- in the field of labor relations (unlawful dismissal or transfer, non-payment of sums due to him, performance of work in dangerous conditions for life and health, etc.), which led to his moral suffering, loss of normal life ties or requiring him additional efforts for organization of his life, the obligation to compensate for moral (non-pecuniary) damage rests with the owner or his authorized body, regardless of ownership, type of activity or sectoral affiliation are subject to Art. 237-1 Code of Laws of Labor of Ukraine.

Since the issue of compensation for non-pecuniary damage is governed by legislative acts that have been put in place at different times, the employer and the employee need to find out in each case the nature of the legal relationship.

Key words: necessary conditions of liability, non-pecuniary damage, amount of non-pecuniary damage, procedure for compensation of harm.

Вступ. Сьогодні дедалі частіше трапляються випадки порушення прав працівників. Така тенденція звісно $€$ фактором негативного суспільного й законодавчого регресу. Саме тому одним із дієвих шляхів протидії даному явищу, а також способом захисту порушення прав працівників $€$ відшкодування моральної шкоди. Часто буває й так, що завдану моральну шкоду не сприймають власне, як шкоду, а тому просто ії ігнорують. Відтак в умовах сьогодення відшкодування моральної шкоди у трудовому законодавстві не виконує своєї першочергової функції - захисту й відновлення порушених прав працівників. Однак конкретних напрацювань, які б стосувалися розгляду даного питання з позиції трудового законодавства, сьогодні, на жаль, не існує, що і зумовило інтерес до питання в контексті виконання поставлених завдань.

Постановка завдання. Актуальність проблеми, яка розглядається, $є$ очевидною 3 огляду на те, що, як зазначає I.В. Лагутіна, реалії сучасного життя доводять необхідність розвитку інституту компенсації моральної шкоди у трудовому праві. Адже більшість позовів працівників про поновлення на роботі, про компенсацію шкоди здоров'ю, про виплату заробітної плати та ін. супроводжуються також вимогами про компенсацію моральної шкоди [12, с. 197]. Тому назріла потреба визначенні та конкретизації у трудовому законодавстві тих положень, які безпосередньо стосуються компенсації моральної шкоди працівникові внаслідок порушення його трудових прав [13, с. 97].

Результати дослідження. Відповідно до положень Конституції України ${ }^{1}$, зокрема ст. 32, 56, 62 і чинного законодавства, фізичні та юридичні особи мають право на відшкодування моральної (немайнової) шкоди, заподіяної внаслідок порушення їх прав і свобод та законних інтересів.

Закон України «Про охорону праці» у ст. 12 вперше в трудовому законодавстві передбачив відшкодування моральної шкоди, заподіяної трудовим каліцтвом або іншим ушкодженням здоров'я, пов'язаним з виконанням трудових обов'язків. Цей закон зробив спробу

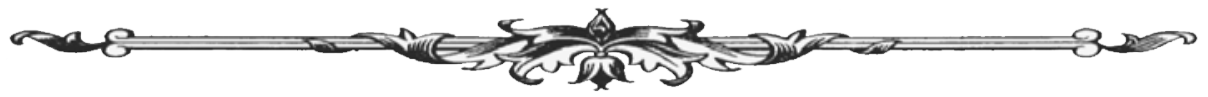


сформулювати поняття моральної втрати як страждань, заподіяних працівникові внаслідок фізичного чи психічного впливу, що спричинило погіршення або позбавлення можливостей реалізації ним своїх звичок і бажань, погіршення відносин з оточуючими людьми, інші негативні наслідки морального [3]. Положення цієї статті були відтворені вперше у ст. 173-1 КЗпП. У 1999 р. ця стаття була відмінена, а замість неї була введена ст. 237-1 КЗПП у такій редакції:

Ст. 237-1КЗПП. Відшкодування власником або уповноваженим ним органом моральної шкоди.Відшкодування власником або уповноваженим ним органом моральної шкоди працівнику провадиться у разі, якщо порушення його законних прав призвели до моральних страждань, втрати нормальних життєвих зв’язків і вимагають від нього додаткових зусиль для організації свого життя.

Порядок відшкодування моральної шкоди визначається законодавством.

Слід сказати, що відповідно до ст. 237-1КЗпП за наявності порушення прав працівника у сфері трудових відносин (незаконного звільнення або переведення, невиплати належних йому грошових сум, виконання робіт у небезпечних для життя і здоров'я умовах тощо),яке призвело до його моральних страждань, втрати нормальних життєвих зв'язків чи вимагає від нього додаткових зусиль для організації свого життя, обов'язок по відшкодуванню моральної (немайнової) шкоди покладається на власника або уповноважений ним орган незалежно від форми власності, виду діяльності чи галузевої належності.

Умови відшкодування моральної (немайнової) шкоди, передбачені укладеним сторонами контрактом, які погіршують становище працівника порівняно 3 положеннями ст. 237-1 КЗпП чи іншим законодавством, згідно зі ст. 9 КЗпП є недійсними.

У редакції Закону № 229-IV (229-15) від 21 листопада 2002 р. ст. 12 Закону України «Про охорону праці» було скасовано. Це було кроком вперед, тому що ст. 12 Закону України «Про охорону праці» передбачала відшкодування моральної (немайнової) шкоди лише за шкоду викликану небезпечними і шкідливими умовами праці. Ст. 237-1 КЗпП ширша за змістом оскільки передбачає відповідальність за будь-яке правопорушення власника.

Аналізуючи цю статтю постає питання про тлумачення словосполучення «законних прав». Н.В. Хуторян вважає, що під «законним правом» слід розуміти будь-яке суб'єктивне право, що виникло у працівника як сторони трудових правовідносин, тобто в результаті виникнення трудових правовідносин з власником або уповноваженим ним органом. У статті йдеться не лише про порушення трудових прав, а про порушення будь-яких прав. На нашу думку, роботодавець повинен за трудовим законодавством відшкодовувати моральну шкоду лише у разі порушення трудових прав, у разі ж порушення інших прав відповідальність за моральну шкоду повинна наставати за нормами цивільного законодавства чи законодавства тієї галузі права, яка регулює і охороняє відповідні відносини[5].

Ст. 237-1 КЗпП визначає моральну шкоду як:

- моральні страждання;

- втрата нормальних життєвих зв'язків, які вимагають від потерпілого додаткових зусиль для організації свого життя.

«Моральні страждання» і «втрати життєвих зв’язків» використовуються у визначенні як однопорядкові елементи моральної шкоди, а не як підпорядковані і взаємозалежні один одному, втрата нормальних життєвих зв’язків не викликана моральними стражданнями i, навпаки, моральні страждання спричиненні не втратою нормальних життєвих зв'язків, а той і другий елемент викликані порушенням законних прав працівника. Причому не всякі втрати нормальних життєвих зв'язків можна підвести під поняття моральної шкоди, а лише ті, які вимагають від працівника додаткових зусиль з організації свого життя [5].

Враховуючи, що відшкодування моральної шкоди працівнику в певних випадках регулюється цивільним законодавством слід розглянути поняття «моральна шкода» за цивільним законодавством.

Моральна шкода полягає:

- у фізичному болю та стражданнях, яких фізична особа зазнала у зв’ язку з каліцтвом або іншим ушкодженням здоров'я;

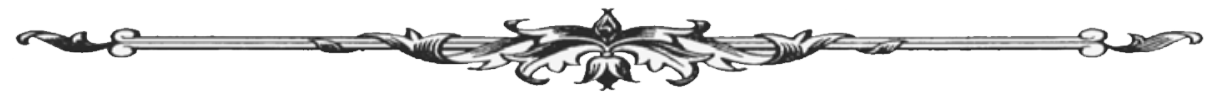


- у душевних стражданнях, яких фізична особа зазнала у зв’язку з протиправною поведінкою щодо неї самої, членів її сім’ї чи близьких родичів;

- у душевних стражданнях, яких фізична особа зазнала у зв'язку із знищенням чи пошкодженням іiі майна;

- у приниженні честі, гідності, а також ділової репутації фізичної або юридичної особи (ст. 23 ЦК) [6].

Аналізуючи цю статтю, бачимо, що Цивільний кодекс не дає загального визначення моральної шкоди, а, по суті, визначає перелік випадків, коли ця шкода настає. Отже, постає питання: а що саме є моральна шкода?

Моральна шкода - це моральні або фізичні страждання, які особа зазнала у результаті протиправного діяння (бездіяльності), що порушує її особисті немайнові або майнові права.

Під моральними стражданнями як емоційно-вольовими переживаннями людини варто розуміти пережиті нею почуття приниження, роздратування, пригніченості, гніву, сорому, розпачу, неповноцінності, стану психологічного дискомфорту тощо.

Під фізичними стражданнями варто розуміти фізичний біль, який зазнала особа у зв’язку із вчиненим проти неї насильством або заподіянням шкоди здоров'ю.

Процедура відшкодування моральної шкоди поєднана 3 труднощами. Доведення факту заподіяння такої шкоди, з’ясування підстав іiі відшкодування вимагає дослідження обставин настання моральної шкоди.

Відповідно до загальних підстав цивільно-правової відповідальності обов’язковому з'ясуванню при вирішенні спору про відшкодування моральної (немайнової) шкоди підлягають: наявність такої шкоди, протиправність діяння іiі заподіювана, наявність причинного зв'язку між шкодою і протиправним діянням заподіювана та вини останнього в її заподіянні. Суд, зокрема, повинен з'ясувати, чим підтверджується факт заподіяння позивачеві моральних чи фізичних страждань або втрат немайнового характеру, за яких обставин чи якими діями (бездіяльністю) вони заподіяні, в якій грошовій сумі чи в якій матеріальній формі позивач оцінює заподіяну йому шкоду та з чого він при цьому виходить, а такожінші обставини, що мають значення для вирішення спору. (п. 5 Постанови Пленуму Верховного Суду України «Про судову практику в справах про відшкодування моральної (немайнової) шкоди» № 4 від 31 березня 1995 р.) [7].

На практиці трапляються випадки, коли потерпілі, обгрунтовуючи свою заяву, як на доказ посилаються на витяг з акта освідування у МСЕК про встановлення відсотка втрати професійної працездатності, вказуючи на те, що обмеженість професійної працездатності і є фактом заподіяння моральної шкоди.

Усвідомлення потерпілим своєї обмеженості у виконанні професійних обов'язків тягне для нього певні негативні наслідки морального характеру. Але один лише факт втрати професійної працездатності не тягне відшкодування моральної шкоди, оскільки він погашається відшкодуванням втраченого заробітку або відповідної його частини, відшкодуванням потерпілому витрат на медичну і соціальну допомогу, виплати одноразової допомоги, яка забезпечує фінансову можливість для соціальної реабілітації потерпілого [8].

Висновком медичних органів як підставою для відшкодування такої шкоди може бути: висновок лікаря, який лікує (лікаря психіатра), лікувально-профілактичних закладів або відповідних медичних комісій про перенесений психологічний стрес внаслідок трудового каліцтва та його наслідків, про депресію, що спостерігається, та інші негативні фактори стану потерпілого.

Такі висновки необхідно розглядати у комплексі з іншими документами та відомостями про потерпілого. При оцінці медичних висновків важливо встановити час настання негативних наслідків морального характеру і причину їх виникнення.

Визначається, чи мав місце факт моральної шкоди у зв'язку з конкретними небезпечними або шкідливими умовами праці потерпілого (пов'язаний з виконанням його професійних обов'язків) чи негативні наслідки настали від загальних шкідливих факторів, які наявні у даному регіоні. Так, у населення, яке проживає у промислово-насичених районах, відповідно

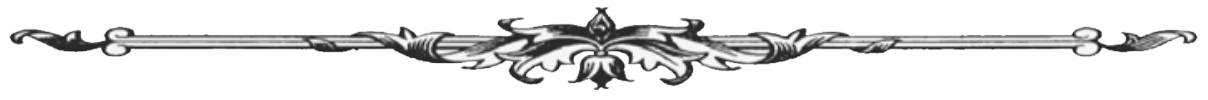


до проведених досліджень спостерігається підвищений рівень (до 50\% проживаючих) різних психічних розладів, неврозів, загострень нервових захворювань. У ряді випадків спостерігається стан «пост травматичного стресу», не викликаний конкретною травмою. Така ситуація пояснюється незадовільною екологічною обстановкою у таких регіонах. Тому необхідно відокремлювати шкідливі наслідки, які настали в результаті конкретної професійної діяльності потерпілого, від наслідків пов’язаних з впливом загальних шкідливих факторів.

У разі психічних розладів у потерпілого з метою, визначення причинно-наслідкового зв'язку, встановленого діагнозом, з шкідливими або небезпечними умовами праці можливе призначення судово-психіатричної експертизи, використання даних санітарних, екологічних та інших служб.

Відправляючись від характеристик емоційної сфери особи потерпілого, які виявляються у спілкуванні, важливо простежити їх вплив наскладання типового для нього стилю спілкування, вироблення нових способів поведінки, з урахуванням індивідуальних характеристик кожного потерпілого, нове формування його комунікативної поведінки, труднощі виникнення нових структурних утворень в особи, ії потреб, цінностей, орієнтацій, зміни образу, розуміння себе і ставлення до себе, складності у виявленні нових психологічних установок, переживання при спілкуванні з оточуючими в галузі життєдіяльності потерпілого - його побут, відпочинок, взаємовідносини у сім’ї, з друзями по спільному відпочинку, з іншими. Названі психологічні фактори й особливості особистості потерпілого необхідно враховувати при розгляді визначальних наслідків настання моральної шкоди.

Так, до ушкодження здоров'я потерпілий мав певні інтереси, яким внаслідок свого фізичного чи психічного стану не може приділяти увагу. В результаті стану здоров'я - вимушена відмова від інтересів, організація звиклого дозвілля викликає певні моральні страждання і негативно позначається на його здоров’ї, потерпілий впадає в депресію, у нього виникають різні психози, нервовість та інші відхилення у поведінці і спілкуванні з оточуючими [1].

Але в кожному конкретному випадку необхідно оцінювати важливість (істотність) для потерпілого його звичок і бажань залежно від життєвих цілей і установок. Наприклад, якщо участь у художній самодіяльності для потерпілого було не просто тимчасовим захопленням, а мала на меті в подальшому стати його професією (звичним способом життя), то в цьому разі втрата такої можливості є серйозною моральною травмою, за яку у поєднанні з іншими негативними наслідками морального характеру може настати відповідальність власника. Проте при оцінці таких фактів важливо враховувати реальність реалізації втраченої можливості (бажання) потерпілого.

Тільки комплексна оцінка всіх наявних відомостей про потерпілого дозволяє встановити заподіяну йому моральну шкоду[9].

Розмір відшкодування моральної (немайнової) шкоди суд визначає залежно від характеру й обсягу страждань (фізичних, душевних, психічних тощо), яких зазнав позивач, характеру немайнових втрат (їх тривалості, можливості відновлення тощо) та 3 урахуванням інших обставин. Зокрема, враховуються стан здоров’я потерпілого, тяжкість вимушених змін у його життєвих і виробничих стосунках, ступінь зниження престижу, ділової репутації, час та зусилля, необхідні для відновлення попереднього стану, добровільне - за власної ініціативою чи за зверненням потерпілого - спростування інформації редакцією засобу масової інформації. Суд має виходити із засад розумності, виваженості та справедливості (п. 9 Постанови Пленуму Верховного Суду України «Про судову практику в справах про відшкодування моральної (немайнової) шкоди» № 4 від 31 березня 1995 р.).

Ще одна особливість відшкодування моральної шкоди працівнику, завданої з вини роботодавця, полягає в тому, що законодавець не встановлює переліку випадків, які зумовлюють настання цієї шкоди і становлять підстави їі відшкодування. Як зазначає Вищий спеціалізований суд України з розгляду цивільних і кримінальних справ, у Листі «Про практику застосування судами при розгляді справ окремих норм трудового права» (№ 10-1389/0/4-12 від 27 вересня 2012 р.), КЗПП не містить будь-яких обмежень чи виключень для компенсації моральної шкоди у разі порушення трудових прав працівників [17].

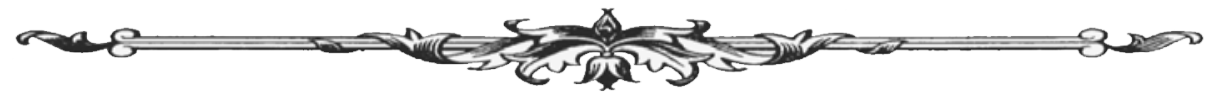


Висновки. Як ми бачимо, щодо розміру відшкодування моральної шкоди, ні Кодекс законів про працю, ні Цивільний кодекс України, ні інший законодавчийакт не встановлює його розмір (навіть мінімальний). Зрозуміло, що не можливо встановити розмір для кожного конкретного випадку, але ми вважаємо необхідним закріпити на законодавчому рівні мінімальний розмір, що буде унеможливлювати випадки, коли розмір компенсації занадто малий.

\section{Список використаних джерел:}

1. Виприцький А.О. Відшкодування моральної шкоди у кримінальному провадженню. Кримський юридичний вісник. 2010. Вип. 1 (3). С. 93-99.

2. Закон України «Про охорону праці» від 14 жовтня 1992 р. Відомості Верховної Ради (ВВР). 1992. № 49. Ст. 668.

3. Петренко В. Деякі питання компенсації моральної (немайнової) шкоди. Право Украӥни. 2015. № 5-6. С. 29-30.

4. Кодекс законів про працю України від 10 грудня 1971 р. Відомості Верховної Ради. 1971. Додаток до № 50. Ст. 3754.

5. Хуторян Н.М. Теоретичні проблеми матеріальної відповідальності сторін трудових правовідносин : монографія. Київ : Інститут держави і права ім. В.М. Корецького ПАН України, 2002. 264 с.

6. Цивільний кодекс України від 16 січня 2003 р. Голос України. 2003. № 45-48.

7. Про судову практику в справах про відшкодування моральної (немайнової) шкоди : Постанова Пленуму Верховного Суду України від 31 березня 1995 р. № 4. URL: http://zakon1.rada.gov.ua/laws/show/v0004700.

8. Невстінний М. Моральна шкода та питання відшкодування ії на практиці. Право України. 1995. № 7. С. 47-48.

9. Невшіінний М. Критерії визначення моральної шкоди у зв'язку з трудовим каліцтвом або іншим ушкодженням здоров’я. Право Украӥни. 1996. № 4. С. 49-50.

10. Подорожний Є.Ю. Різновиди матеріальної відповідальності роботодавцям. Науковий вісник Ужгородського національного університету. Серія Право. Вип. 37. Т. 2. 2016. С. 84-87.

11. Лега О.В. Економіко-правові аспекти матеріальної відповідальності облікових працівників. Вісник ЖДТУ. 2010. № 3 (53). С. 150-151.

12. Лагутіна I.B. Реалізація права працівника на компенсацію моральної шкоди як суб'єктивного трудового права. Вісник Міжнародного гуманітарного університету. Серія «Юриспруденція». 2014. № 8. С. 196-198.

13.Годованець Ю.С. Відшкодування моральної шкоди, завданої порушенням трудових прав працівника як вид трудоправової відповідальності роботодавця. Науковий вісник ЛДУВС. 2018 № 2. С. 97-106.

14.Про практику застосування судами при розгляді справ окремих норм трудового права: лист Вищого спеціалізованого суду з розгляду цивільних та кримінальних справ від 27 вересня 2012 р. № 10-1389/0/4-12. Часопис ичивільного і кримінального судочинства. 2013. № 1 (10). С. 22-24.

15.Виприцький А.О. Щодо виникнення трудових правовідносин. Адміністративна реформа та проблеми вдосконалення діяльності правоохоронних органів : матеріали Міжнар. наук.-практ. конф. (Сімферополь, 11-12 грудня 2008 р.). Сімферополь : Кримський юрид. Ін.-т ОДУВС, 2008. С. 219-220.

16.Виприцький А.О. Порядок визначення та компенсації моральної (немайнової) шкоди. Кримський юридичний вісник. 2009. Вип. 3 (7). С. 48-55.

17.Виприцький А.О. Особливості відшкодування моральної шкоди. Пріоритети нової економіки знань в XXI сторіччі : Матеріали Всеукр. наук.-прак. конф. (Ялта, 12-14 травня 2010 р.). Ялта : Дніпроп. Нац. ун-т. ім. О. Гончара та Придвськ. держ. Академія будівництва та архітектури, 2010. С. 242-246.

18. Виприцький А.О. Ділова репутація юридичної особи: немайнова шкода. Перспективи та проблеми адміністративної реформ в України: матеріали Всеукр. наук.-прак. конф. (Запоріжжя, 1 березня 2007 р.). Запоріжжя : Запорізький Нац ун-т, 2007. С. 29-32.

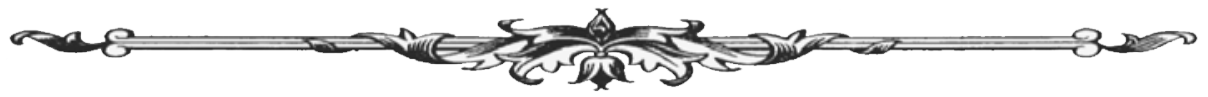

